\title{
In Conversation with the Ancestors: Indigenizing Archaeological Narratives at Acadia National Park, Maine
}

\author{
Bonnie Newsom ${ }^{1, *}$, Natalie Dana Lolar ${ }^{1}$ and Isaac St. John ${ }^{2,3}$ \\ 1 Department of Anthropology, University of Maine, 5773 South Stevens Hall, Orono, ME 04469, USA; \\ natalie.dana.lolar@maine.edu \\ 2 Tribal Historic Preservation Office, Houlton Band of Maliseet Indians, 88 Bell Road, Littleton, ME 04730, USA; \\ istjohn@maliseets.com \\ 3 Anthropology Department, University of New Brunswick, Annex C 28, Fredericton, NB E3B 5A3, Canada \\ * Correspondence: bonnie.newsom@maine.edu
}

check for updates

Citation: Newsom, Bonnie, Natalie Dana Lolar, and Isaac St. John. 2021 In Conversation with the Ancestors: Indigenizing Archaeological Narratives at Acadia National Park Maine. Genealogy 5: 96. https:// doi.org/10.3390/genealogy5040096

Received: 1 June 2021

Accepted: 28 October 2021

Published: 3 November 2021

Publisher's Note: MDPI stays neutral with regard to jurisdictional claims in published maps and institutional affiliations.

Copyright: (c) 2021 by the authors. Licensee MDPI, Basel, Switzerland. This article is an open access article distributed under the terms and conditions of the Creative Commons Attribution (CC BY) license (https:// creativecommons.org/licenses/by/ $4.0 /)$.

\begin{abstract}
In North America, Indigenous pasts are publicly understood through narratives constructed by archaeologists who bring Western ideologies to bear on their inquiries. The resulting Eurocentric presentations of Indigenous pasts shape public perceptions of Indigenous peoples and influence Indigenous perceptions of self and of archaeology. In this paper we confront Eurocentric narratives of Indigenous pasts, specifically Wabanaki pasts, by centering an archaeological story on relationality between contemporary and past Indigenous peoples. We focus on legacy archaeological collections and eroding heritage sites in Acadia National Park, Maine. We present the "Red Paint People" myth as an example of how Indigenous pasts become distorted through archaeological narratives influenced by Western ideologies and offer a framework for indigenizing archaeological narratives constructed previously through Western lenses, using Indigenous language and community engagement to carry out the study.
\end{abstract}

Keywords: Indigenous archaeologies; critical Indigenous studies; Maine archaeology; Wabanaki

\section{Introduction}

For over a century, North American archaeologists have operated under a model that assumes the right to excavate, research, and interpret Indigenous archaeological sites and associated material culture with little to no consultation with the people whose heritage these places represent. Although archaeology has undergone a transformation in the past 30 years that has reformed some of these practices, narratives of Indigenous pasts that objectify past peoples and impose Eurocentric interpretations on Indigenous heritage are slow to change.

An example of this is evident in a common Maine archaeology myth (Sanger 2000) centered on a group referred to as the "Red Paint People," so-called because of their practice of including powdered hematite or red ochre in the graves of the deceased. The "Red Paint People" narrative refers to a distinct group of people who occupied Maine between 5000 and 3800 years ago; they had a marine orientation, hunted swordfish, fashioned unique and elaborate grave goods, and vanished mysteriously when another group of people moved into the region with different mortuary practices and material culture. This is not an Indigenous story nor is it accepted by many in the archaeological community; however, it shapes public perceptions of Indigenous peoples and influences Indigenous perceptions of self and of archaeology.

In this paper, we, as Indigenous archaeologists working in Maine, confront the Eurocentric narratives of Indigenous pasts, specifically Wabanaki ${ }^{1}$ pasts, by centering an archaeological story on the relationality between contemporary and past Indigenous peoples. We do this through a project focused on legacy archaeological collections and eroding heritage sites in Acadia National Park (ANP), Maine. Here, we present the "Red Paint 
People" narrative as an example of how Indigenous pasts become distorted through archaeological interpretations influenced by Western ideologies. We offer an alternative framework for indigenizing archaeological narratives constructed previously through Western lenses using Indigenous language and integrating community voices in carrying out the study. Our aim is not to debunk the "Red Paint People" myth specifically-Sanger (2000) has done that already. Our aim is to highlight it as an example of how the stories of Indigenous pasts become coopted, controlled, and shaped by archaeologists and to offer an alternative model for storying Indigenous heritage.

\section{Background}

The "Red Paint People" concept arose on the public scene in the early part of the twentieth century when antiquarian Warren K. Moorehead publicized the phrase to reference Indigenous people associated with the red ochre-filled graves he excavated while doing fieldwork in Maine (Sanger 2000; Wheeler and Newsom n.d.). Since then, the story has not only been perpetuated through public folklore and archaeological narratives, but it has also been used to challenge Indigenous claims of cultural connectedness to past peoples living in the region in deep time. For example, the Peabody Museum of Archaeology and Ethnology at Harvard denied Wabanaki repatriation claims to human remains and funerary objects associated with the red ochre burial tradition. Although the Wabanaki tribes provided linguistic, folkloric and archaeological information as evidence of cultural affiliation between contemporary Wabanaki peoples and those associated with the red ochre burial tradition, museum representatives claimed that the evidence was insufficient to support a cultural affiliation determination (Newsom 2008; Wheeler and Newsom n.d.).

Repatriation is one area where archaeological narratives can erode Indigenous rights. However, archaeological perspectives that disassociate Indigenous peoples from pasts and places have broader effects. They influence Indigenous rights to lands, cultural patrimony, indigeneity, federal recognition, and identity. They also reinforce the notion that contemporary Indigenous peoples are new-comers to this land (Kolodny 2021). This view positions Indigenous peoples as settlers which contradicts and negates oral narratives and Wabanaki perspectives of connectedness to place. Kolodny (2021) discusses this in her intervention of contemporary racist rhetoric and white supremist ideologies in the U.S. where she criticizes Bourque $(2001,2012)$ for perpetuating the "Red Paint People" narrative and for his testimony against the Penobscot Nation in their legal fight for jurisdiction over the Penobscot River.

Sanger (2000) attempted to shift the narrative away from the Eurocentric story of a lost race of people by challenging it as one of three common myths in Maine archaeology. He notes that "There is no great mystery, no justification to invoke a seafaring culture with Old World connections, or thinly-veiled racist suggestions of superiority relative to more modern Native peoples" (Sanger 2000, p. 154). Additionally, Wabanaki people have maintained a position of cultural connectedness to all past Indigenous peoples in Maine based on oral traditions, linguistic connections, and consistent connections to territory (Newsom 2008). Despite this, and despite advances in archaeological understandings about the red ochre burial tradition (Robinson 1992, 1996, 2004), the "Red Paint People" narrative maintains its foothold in the minds of Maine's public. What is more problematic is that it arises in Indigenous conversations about archaeology and Wabanaki pasts, almost to the exclusion of all other archaeological topics. Through our experiences as Indigenous archaeologists working within our communities, we have witnessed how the "Red Paint People" narrative has influenced how Wabanaki people think about the past and how they view archaeology and archaeologists. Wabanaki people have generally maintained that they are culturally connected to those Indigenous people who practiced the red ochre burial tradition, and they are compelled to reaffirm cultural connections to this particular group in their attempts to deconstruct the dominant narrative which emphasizes the disappearance of a distinct group of people. 
The "Red Paint People" myth achieves staying power largely because it is given credibility via popular media and archaeological literature. For example, a documentary film on the topic tells the story of the "Red Paint People" highlighting it as a mystery and featuring some of the region's most respected archaeologists (Timreck and Goetzmann 1987). As recently as 2017, the story was featured on a local Maine news channel as part of their "Maine Mysteries" series (Bavoso 2017). These forms of media enhance public accessibility to the story. Additionally, it is perpetuated and reinforced through archaeological texts by those who have the Western socio-cultural credentialing to validate the narrative in the eyes of the general public (Bourque 2001, 2012). As a result, Western ideologies and perspectives on the red ochre burial tradition in Maine hold prominence while the Indigenous narrative of cultural connectedness to past peoples in deep time is marginalized and generally un-acknowledged.

Over thirty years ago, Joan Gero (1989, p. 96) suggested that "the way in which any group of people values and maps its past is a social practice, embedded in a larger logic and a broader set of actions." Archaeology, and by extension the narratives that the discipline produces, are constructs of Western ideologies that, according to Gero (1989, p. 97), "erode" and "supplant" alternative ways of approaching the past. Her discussion of the varied interpretations of New England "beehive" rock structures is relevant here in that she shows the dichotomies and tensions between archaeologists and local citizens surrounding interpretations of these structures, which have been interpreted as creations of Celtic Druids, early Culdee/Ibiric monks, Mediterranean peoples, Indigenous peoples, and settler farmers (Gero 1989). Although the groups and topics differ from Maine's "Red Paint People" myth, the conclusions Gero (1989) draws from her study of public and professional interpretive tensions surrounding New England beehive structures are relevant here. She writes:

"[ . . the production of a prehistoric past proceeds from an ideology of the present. It is by participating in one or another ideological system that we recognize and gain access to particular archaeological resources (sites and artefacts) [... ]; it is how we acquire a logic of interpretation and reconstruction and it channels the dissemination of information along predetermined networks. Moreover, it provides a means of self-construction, both by the nature of the production tasks we undertake and by the oppositions we form". (Gero 1989, p. 103)

The "Red Paint People" myth and the varied interpretations of the New England beehive structures are products of racialized knowledges constituted and reconstituted by those who seek to maintain control over the narrative. Ideologically these narratives emerge from a socio-cultural system that authorizes archaeologists to map the pasts of others, or to validate Eurocentric claims to territory.

To assert authority over interpretations of Wabanaki pasts, we have undertaken an archaeological study at Acadia National Park (ANP) in Maine designed to re-frame Indigenous pasts using a "new model" for Maine archaeology that brings Indigeneity to bear on archaeological interpretations through language and relationality. We employ strategic decolonizing action through our own agency as Indigenous archaeologists to dismantle Eurocentric interpretations of past Indigenous peoples. We seek to deconstruct how Wabanaki pasts are explored, presented and contribute to the growing body of critical Indigenous studies (Goeman 2013; Moreton-Robinson 2004, 2016; O’Brien 2010), to "challenge the power/knowledge structures and discourses through which Indigenous peoples have been framed and known" (Moreton-Robinson 2016, p. 5). We confront racialized knowledges about past Indigenous peoples in pre-colonial Maine by situating our research within the ideological framework of Wabanaki language and community service.

\section{Theoretical Framework}

Our effort to deconstruct and transform archaeological narratives is guided by Indigenous archaeologies theory (Atalay 2006; Nicholas and Andrews 1997; Wobst and Smith 
2005; Wobst 2005) which seeks to decolonize archaeology in support of an equitable and just archaeological practice. Indigenous archaeology is defined as archaeology "with, for, and by" Indigenous peoples (Nicholas and Andrews 1997) and according to Nicholas (2008, p. 1660), seeks an archaeology that is "representative of, responsible to, and relevant for Indigenous communities." As Wabanaki archaeologists, this type of approach is, and has always been, central to the work we do. Indigenous archaeologies approaches have transformed the role of Indigenous peoples in the discipline through efforts to place Indigenous communities, values, and agendas at the forefront of archaeological inquiry and practice (Wobst 2005).

As noted by Wobst (2010, p. 22), Indigenous archaeologies aid in decolonizing the discipline by encouraging archaeologists to "replace obviously biased representations with accounts that more sensitively report what is there and how it got to be that way, rather than filtering one's observations through the colonizers' /administrators' lens." Atalay (2006, p. 292) points out that Indigenous archaeology[ies] center on "research that critiques and deconstructs Western archaeological practice as well as research that works toward recovering and investigating Indigenous experiences, practices, and traditional knowledge systems." We apply these philosophies here by showcasing the "Red Paint People" narrative as one that erroneously shapes the perspectives of Maine's Indigenous peoples and their pasts, and by offering an alternative framework through which to conduct archaeological research on Wabanaki pasts.

We also draw here from Ingold $(2013$, p. 3) who states that "Anthropology is studying with and learning from; it is carried forward in a process of life and affects transformations within that process." This is at the heart of our approach. Through our work we seek to study with and learn from our ancestors, to elevate them as teachers and story-tellers in their own right using their (our) language as an integral part of our conversations. This shelters them from Western epistemologies that situate them as empirical objects of study and moves them toward a more appropriate status as members of our kin group whose offerings contribute to our well-being. By combining these theoretical tools and applying them to our research we prioritize Indigenous people and Indigenous concepts of connectedness within our archaeological inquiry.

\section{Our Stories}

The following stories are individual narratives offered by the authors as three Wabanaki archaeologists working in Maine. As Indigenous archaeologists, we come to our work from a place of love- a love for our ancestors, our communities, and our descendants. Our commitment to the well-being of our people, both forward and back, shapes not only the archaeological questions we ask but also why we ask them. This is very different from those who narrate and perpetuate the "Red Paint People" myth. We seek to move far beyond the public perceptions of our pasts and bring new knowledges and approaches to archaeological research.

Here, we preface our discussion of our research at ANP with our own stories in order to contextualize our approach ideologically. We acknowledge that our ideologies influence our work, but as Indigenous archaeologists trained in Western academic settings, we also acknowledge the influence these experiences have on our ideologies. Where we are distinguished from our non-Indigenous colleagues is in why we choose to do this work, and this is articulated in the stories that follow.

\subsection{Isaac's Story}

My desire to be involved in archaeology stems from learning about my tribe's history from second-hand, non-Indigenous sources. Throughout my academic career, I was introduced to sources on pre- and post-contact times and sources on Indigenous cultural practices-all of which reflected a Westerner looking in from the outside. Native faces and voices in academia were rare and if an Indigenous author was suggested, it always came as an afterthought. As I matured as a scholar, I became more exposed to broader Indigenous 
academic approaches and pools of knowledge. I soon realized that I had a lot of catching up to do to stand with confidence as an Indigenous archaeologist. I felt conflicted asking for help while figuring out where my Indigenous knowledge stopped and started. I felt like I was not supposed to be in that sphere, having only seen myself and my people as the objects of study, never as authors or researchers.

This "catching up" process and awakening to my own positionality made me determined to ensure that other Indigenous people did not have to go through the same experience. It is disconcerting to come to the academic table thinking you have an entire card deck, only to realize that people are playing an entirely different game. I want to ensure that those coming after me do not have to learn about our history and culture from secondhand sources, from outsiders looking in.

Our work to include Wabanaki people and make archaeology accessible helps us move towards a decolonized archaeology. We are normalizing Indigenous faces researching our own heritage and presenting the results. Seeing, hearing, and knowing that the researcher has knowledge of your culture, not because they have assumed the right to study you for years, but because they are from your culture, is a novel idea, becoming less novel by those who commit to a decolonized academia.

The Wabanaki and Western worlds have mixed and mingled to the point of becoming entangled. As Wabanaki people, we are living in a very different world from that of our ancestors, but we are also not living in the world of the colonizer. It is in this liminal space where we, as Indigenous archaeologists, can choose ways that use archaeology to aid our communities in lifting the colonial blanket that is smothering our Indigeneity and sovereignty.

As an Indigenous archaeologist, I recognize that colonization forces language onto oppressed peoples and imposes hierarchies by way of jargons. This creates boundaries between those inside and outside "the know." What better way to create a social hierarchy of the colonized than to keep information about their own culture behind a wall of jargon? With our decolonizing work ("our" being Indigenous scholars as a whole, as well as the authors here), we are creating a means to tear down the linguistic walls that past researchers have erected. This transforms archaeology in a small but powerful way by ensuring archaeological information is relevant and accessible to Indigenous people.

\subsection{Bonnie's Story}

The day I finally committed my life to archaeology cycles through my mind often. As an undergraduate student, I loved anthropology and science, but as an Indigenous woman I could not make the connection between anthropology and work that was meaningful to Wabanaki people. I had considered archaeology as a potential career, but only in passing as there was a dark side to archaeology that plagued me-one linked to the desecration of thousands of Native American graves in the name of science. Archaeology's history pushed me away.

Then, one summer I opted to enroll in an archaeology field school offered by a local museum. The site was located on the coast of Maine, and I remember being on site for the first time and thinking how obvious it was why my ancestors chose to live at this spot, it was a post-card example of Maine's beautiful coastline with clam flats complemented by a rocky shoreline and an ocean that went on forever.

It was probably day three or four of the field school when I noticed a rock cluster beginning to appear in my pit. As I brushed the dirt away from the rocks, the circular pattern of a fire hearth became clearer, and I noticed something white sitting just outside of the cluster. I cleared the dirt away from it and then picked it up. I had no idea what I was holding. It was long and white and pointed at one end. The other end appeared broken. I asked the field director if he could identify it and he told me it was a drilled tooth from a very large bear. At first, it was not clear to me why anyone would need to drill a bear tooth, and then it clicked - this was not a tool for hunting or fishing, not a sherd from a cooking pot-it was a fragment of a necklace, a 2000-year-old expression of beauty created 
by someone I had a cultural connection to. Within that brief moment of awareness, I was transported back in time visualizing my ancestors on the land. Questions about who wore the bear tooth arose in my mind-was it made as a lover's gift? How did they feel when they lost it? Was it ripped off and thrown to the fire in anger or perhaps given to the fire as part of an offering? I wanted the Indigenous story and admittedly it is one we will never know; but I will never forget that feeling of holding something that may have touched the chest of one of my ancestors. It was a feeling of intimacy and one that grounded me to who I am and where I come from and the thing is, nobody can ever take that feeling away. It is a feeling I want other Wabanaki people to experience. It is the connection to our ancestors and heritage that makes us resilient in the face of all the tragedy we encounter as Indigenous peoples and so for me, archaeology supports healing through the reawakening of our cultural relationships with our ancestors, with ourselves, and with each other.

\subsection{Natalie's Story}

One of my first experiences with archaeology was at a field school when I was 16 years old, and I found a piece of pottery with the thumbnail imprint of my ancestors in the back. I placed my thumbnail into the imprint and this experience created a powerful connection that changed my life. We, as Wabanaki people, have had our connections to this material culture severed, through no fault of our own. My thumbnail experience represents a moment of healing and reconnection. Engaging with our ancestors through their material culture can create feelings of connection, spark stories, and reteach us as a people. I look at archaeology as a way to learn more about my ancestors, a way to reconnect, a way to bring back some of the knowledge that has been taken from us or forgotten. Our stories are like a spider's web, connecting us with our ancestors, our environment, animals, and more than human others; however, when the web is without anchors, it can sometimes float in the wind. Archaeological knowledge can anchor the web to a tangible spot where it can be observable. Through those observations, we can once again maintain conversations with our ancestors; archaeological knowledge is a way to enhance our stories, bring back knowledge, and repatriate knowledge taken from us.

We seek to help facilitate those connections and disseminating knowledge back to the tribes is a top priority for any of the work that we do. Decolonization is needed to recenter Indigenous people on our culture and identity. The questions that the tribes would like answered and what they want to see drives our work. By incorporating Indigenous knowledge and worldviews in an alternate way to archaeological inquiry, we bring our traditional and modern selves together. Western approaches to archaeology have often excluded the human element and disconnected contemporary Indigenous people from our past. Artifacts have become "dancing projectile points on the landscape, with no humans holding them" (Cole-Will 2021, pers. comm.). Indigenous people are not the ones telling the stories of Indigenous pasts. We do not have a strong voice within the archaeological world, yet we need one to ensure that our interpretations of our pasts are visible to both our communities as well as others. I do this work to bring the ancestors and contemporary people back together, with the intent of strengthening our culture and the story of ourselves.

\section{Wabanaki Connections, Past, Present, and Future}

We share our personal stories here to distinguish our motivations from our nonIndigenous colleagues. Our choice to pursue archaeology as a career was inspired by our desire to serve our communities. We were never collectors seeking artifacts, nor did we seek to build a career studying the past lifeways of "others." We came to and travel through the discipline to serve Wabanaki people.

We all came to archaeology through a Western system of education, and we carry out our work from within and without that system. As Indigenous archaeologists we converse with our ancestors using multiple methods-oral histories, elder teachings, ethnohistoric 
accounts, and archaeological data. Archaeology is only one of a suite of tools we use to connect with our ancestral past.

A common theme within our stories is connectedness and this is why the "Red Paint People" myth could never emerge from us as archaeologists. We seek connections and re-connections with our ancestors, communities, and culture. Therefore, the research questions we ask and how we approach the answers will always circle back to connections between past, present, and future Wabanaki people. This does not mean that we discount archaeological data. It simply means that we explore those data with a "logic of interpretation" (Gero 1989) framed by our lived experiences and motivations. In the next section, we describe current research underway that fulfills our goals as Indigenous archaeologists, offers a framework for re-visiting archaeological interpretations of the past and integrates Indigenous communities, their heritage rights, and their perspectives into an archaeological project.

\section{Old Collections, New Analyses, and New Narratives}

As Indigenous archaeologists we situate our research in our ancestral homeland-the Maine/Canadian Maritime region of northeastern North America. This particular project centers on archaeological sites in the Acadia National Park (ANP) in mid-coast Maine. This Park is part of the U.S. National Park System and there are at least 24 known Indigenous cultural spaces (also known as archaeological sites) in the ANP that preserve remnants of past Indigenous lifeways. Collectively they represent a timespan from roughly 4000 to 500 years ago (Wright et al. 2004, p. 272). Many of these spaces are shell heaps created by past Wabanaki peoples who deposited large quantities of clam shells on the landscape. Shells reduce the acidity of the soil and aid in the preservation of material culture such as bone tools and other types of organics which would otherwise decompose in Maine's acidic soils. For Maine's Indigenous communities, shell heaps represent a built heritage that helps tell the story of our ancestors and our cultural connections to place. They reflect past lifeways of Indigenous families who left behind belongings, gifts, creations, art, and activity areas for us to learn from. Archaeologically, these are frequently referred to as hunter-gatherer datasets comprised of artifacts and features-terminology constructed through Western epistemologies and designed to create a common empirical language to communicate and objectify the past.

Our examination of these spaces is inspired by their vulnerability to climate changerelated threats, the Park Services' and our responsibility for making heritage stewardship decisions, and our commitment to learning from our ancestral past. Sea level rise is eroding the shell heap sites at an alarming rate-a process accelerated by irregular freeze thaw cycles that compromise the integrity of the shell matrix. Increasing storm intensity from extreme weather events poses an additional threat. These factors, combined with human impacts along the coast, make the shell heaps some of the most fragile cultural heritage sites in our homeland.

Effective management of the shell heap sites requires a comprehensive understanding of these threats as well as their cultural and research value. Archaeological research in the ANP has been intermittent, and little analysis or interpretation of site contents or the cultural and paleoenvironmental value of these resources has occurred (Wright et al. 2004). This has created a gap in the knowledge about Maine's Indigenous peoples and their connections to ANP lands. The goals of our research are to address the gaps in knowledge on past Indigenous use of the park lands, and to use information acquired through this research as a basis for knowledge exchange and communication with Wabanaki communities, so that they are fully informed to participate in stewardship decisions for Indigenous heritage spaces in ANP.

In the 1970s and 1980s, Sanger $(1974,1981)$ conducted several archaeological investigations of Indigenous heritage sites in the park and generated technical reports on the research. These investigations produced collections of material culture (stone and bone tools, ceramics, and food remains) which have been curated at ANP. The existing reports 
and material culture collections form the basis of our inquiry, and we are re-visiting the written products and re-analyzing ceramics and stone tools recovered during those early studies. For the most part, the content of the written reports and the collections have remained under Park Service control and, until recently, Wabanaki communities had not been exposed to either.

We selected records and existing collections from two locations to examine. One is an offshore island at Isle au Haut and the other is on the mainland at Frazer Point. Both locations reflect at least two millennia of Indigenous engagement with these spaces and each provides unique opportunities to explore past Wabanaki lifeways. For example, Isle au Haut is home to a quarry site-a place that provided our ancestors stone material to work with. At Frazer Point our ancestors left behind a bird bone flute and the remains of the now extinct great auk and sea mink-all of which help us understand their/our connections to other-than-human relatives.

Indigenizing archaeological narratives, practices, and decisions related to cultural heritage spaces is central to our study. Words are value laden (Tilley 1989), and the language, terminology, and values inherent in archaeological narratives shape and communicate the story of Wabanaki pasts but may not be accessible to everyone. The following quote is from the Frazer Point archaeology report, and it is not included here to disparage the author as the report was generated for a particular audience; however, it illustrates the kind of language that needs to be transformed to facilitate conversations with Wabanaki people about archaeology and interpretations of material culture from Park sites:

"... the constitution of the faunal remains, the lack of features and ceramics, and the remainder of the artifact assemblage, imply a temporary habitation emphasizing marine ecosystem exploitation and activities in which non-stemmed bifaces played an important role". (Sanger 1981, p. 43)

This excerpt exemplifies how the story of Indigenous pasts becomes cordoned off from Indigenous peoples through a narrative system designed to speak to particular audiences. As Indigenous archaeologists trained in Western approaches to archaeological inquiry, we are deconstructing narrative barriers by serving as translators, and re-narrating the archaeological story for Indigenous audiences. How we communicate archaeological narratives and interpretations is a blend of conventional and unconventional archaeologyrelated terminology, and this approach supports our conversations with our ancestors and communities.

Revisiting and translating the narratives of past archaeological research in ANP is one facet of the language transformation we apply to this study. Our intent here is to reframe archaeological narratives of Wabanaki pasts in the park to better represent Wabanaki world views and perspectives. The second is the integration of Wabanaki terminology into the re-analysis of cultural materials. Our analysis of ceramics and stone tools focuses on our ancestors' choices along the production sequence (Lemonnier 1993). To support and Indigenize this analysis we draw from our Indigenous languages (the languages of our ancestors). This process enhances our material culture descriptions and our interpretations of the collections. For example, the word for arrowhead is "sikuwan" and the word for clay pot is "qahqolunsqey" (Passamaquoddy-Maliseet Language Portal 2021). Using Indigenous language terminology to describe items in the collections accomplishes two things. First, it helps reveal the role of particular items in past Wabanaki lifeways. "Qahqolunsqey", the word for clay pot, is animate. This follows a general convention for words for containers that are used for liquid such as bathtub and pail (Passamaquoddy-Maliseet Language Portal 2021). Terms used for people and animals are often animate. Exploring why clay pots fall into the animate category helps us as archaeologists understand how Indigenous peoples in the past viewed and classified clay pots. Second, the integration of Wabanaki languages into our analysis and interpretation of cultural materials from Isle au Haut and Frazer Point creates an Indigenous vernacular linked to past practices and lifeways. This strengthens Wabanaki languages which are currently endangered. 
Perhaps the most important component of our research at the ANP is the shifting of power and knowledge production to Wabanaki communities. We are re-centering Wabanaki communities in this research in multiple ways. We work closely with the Abbe Museum's Archaeology Advisory Board as we proceed through the project. This group of representatives from the Wabanaki communities offers guidance and serves as a sounding board for us as we undertake our research. Outreach activities currently underway include the development of a video showcasing the sites and research, a webinar series designed for Wabanaki communities on shell heaps and climate change, and an in-person presentation on shell heaps and archaeology at a local Indigenous arts festival. It is through multiple methods of knowledge sharing with Wabanaki communities that narratives like the "Red Paint People" myth begin to fade as our interpretations of our archaeological heritage supplant the dominant narratives framed by Western ideologies.

\section{Conclusions}

In this paper, we have shown how archaeological narratives become enmeshed in the public vernacular to reaffirm Western authority over Indigenous pasts. We highlight the "Red Paint People" myth as one such narrative that has materialized from archaeologists entrusted with authority to interpret the past through their socio-cultural credentials. As Wabanaki archaeologists, we offer a model for archaeological inquiry that Indigenizes archaeological narratives using language and community-focused approaches to explore archaeological data. Through our approach to the analysis and our interpretation of archaeological data we seek to dismantle the Eurocentric narrative that has dominated Indigenous pasts. This, in turn, will redress inequitable archaeological practices by placing the connections between contemporary Indigenous peoples and their ancestral heritage at the center of archaeological inquiry and heritage stewardship.

Author Contributions: Conceptualization, B.N., N.D.L. and I.S.J.; methodology, B.N.; writingoriginal draft preparation, B.N., N.D.L. and I.S.J.; writing—review and editing, B.N., N.D.L. and I.S.J.; funding acquisition, B.N. All authors have read and agreed to the published version of the manuscript.

Funding: This research was funded by a Second Century Stewardship award from Schoodic Institute at Acadia National Park and the National Park Service Cultural Resources Fund.

Institutional Review Board Statement: Not applicable.

Informed Consent Statement: Not applicable.

Data Availability Statement: Not applicable.

Acknowledgments: We thank the editors of this volume for initiating this important contribution to Indigenous studies and the anonymous reviewers whose comments improved this paper significantly. Additionally, we are deeply appreciative of Schoodic Institute at Acadia National Park, the National Park Service, the National Park Foundation, and the David E. Shaw Charitable Trust for their support of our work through the Second Century Stewardship program. The Abbe Museum's Archaeological Advisory Committee in Bar Harbor, Maine has been instrumental in guiding us through our research and we are indebted to them for their good counsel. Finally, we say "Kci Woliwon" (Great Thanks) to our ancestors for sharing their stories and knowledges with us.

Conflicts of Interest: The authors declare no conflict of interest and the funders had no role in the design of the study; in the collection, analyses, or interpretation of data, in the writing of the manuscript, or in the decision to publish the results.

\section{Note}

We use the term Wabanaki here to refer collectively to the Indigenous peoples of Maine who include the Aroostook Band of MicMac Indians, the Passamaquoddy Tribe, the Penobscot Nation, and the Houlton Band of Maliseet Indians. 


\section{References}

Atalay, Sonya. 2006. Indigenous Archaeology as Decolonizing Practice. American Indian Quarterly 30: 280-311. [CrossRef]

Bavoso, Katie. 2017. WLBZ News Center Maine [Maine Mysteries]. Bangor: News Center Maine.

Bourque, Bruce. 2001. Twelve Thousand Years: American Indians in Maine. Lincoln: University of Nebraska Press.

Bourque, Bruce. 2012. The Swordfish Hunters: The History and Ecology of an Ancient American Sea People. New York: Bunker Hill Publishing Inc.

Cole-Will, Rebecca. 2021. Resource Management Program Manager, Acadia NP and Saint Croix Island International Historic Site, Bar Harbor, ME, USA. Personal communication.

Gero, Joan. 1989. Producing Prehistory, Controlling the Past: The Case of New England Beehives. In Critical Traditions in Contemporary Archaeology. Edited by Valerie Pinsky and Alison Wylie. Cambridge: Cambridge University Press, pp. 96-116.

Goeman, Mishuana. 2013. Mark My Words: Native Women Mapping Our Nations. Minneapolis: University of Minnesota Press.

Ingold, Timothy. 2013. Making: Anthropology, Archaeology, Art and Architecture. London: Routledge.

Kolodny, Annette. 2021. Competing Narratives of Ancestry in Donald Trump's America and the Imperatives for Scholarly Intervention. In Decolonizing Prehistory, Deep Time and Indigenous Knowledges in North America. Edited by Gesa Mackenthun and Christen Mucher. Tucson: University of Arizona Press.

Lemonnier, Pierre. 1993. Technological Choices: Transformation in Material Culture Since the Neolithic. New York: Routledge.

Moreton-Robinson, Aileen. 2004. Whiteness, Epistemology and Indigenous Representation. In Whitening Race: Essays in Social and Cultural Criticism. Edited by A. Moreton-Robinson. Canberra: Aboriginal Studies Press.

Moreton-Robinson, Aileen. 2016. Introduction: Locations of Engagement in the First World. In Critical Indigenous Studies: Engagements in First World Locations. Edited by A. Moreton-Robinson. Tucson: University of Arizona Press.

Newsom, Bonnie. 2008. Cultural Affiliation and NAGPRA: A Case Study from Maine. Paper presented at the World Archaeological Congress, Dublin, Ireland, June 29-July 4.

Nicholas, George. 2008. Native Peoples and Archaeology. Amsterdam: Elsevier Inc., pp. 1660-69.

Nicholas, George, and Thomas Andrews. 1997. At a Crossroads: Archaeology and First Peoples in Canada. Burnaby: Archaeology Press.

O'Brien, Jean. 2010. Firsting and Lasting: Writing Indians Out of Existence in New England. Minneapolis: University of Minnesota Press.

Passamaquoddy-Maliseet Language Portal. 2021. Available online: https:/ / pmportal.org (accessed on 23 May 2021).

Robinson, Brian. 1992. Early and Middle Archaic Period Occupation in the Gulf of Maine Region: Mortuary and Technological Patterning. In Early Holocene Occupation in Northern New England. Edited by Brian S. Robinson, James B. Petersen and Ann K. Robinson. Occasional Publications in Maine Archaeology, Number 9. Augusta: Maine Historic Preservation Commission, pp. 63-116.

Robinson, Brian. 1996. A Regional Analysis of the Moorehead Burial Tradition: 8500-3700 B.P. Archaeology of Eastern North America 24: 95-148.

Robinson, Brian. 2004. Multiple Boundaries of the Moorehead Burial Tradition. Northeast Anthropology 66: 15-27.

Sanger, David. 1974. Archaeological Survey of Acadia National Park. Manuscript on File at Acadia National Park. Bar Harbor: Acadia National Park.

Sanger, David. 1981. Archaeological Investigations at Frazer Point and Duck Harbor, Acadia National Park. Manuscript on File at Acadia National Park. Bar Harbor: Acadia National Park.

Sanger, David. 2000. “Red Paint People" and Other Myths of Maine Archaeology. Maine History 39: 3.

Tilley, Christopher. 1989. Archaeology as Socio-Political Action in the Present. In Critical Traditions in Contemporary Archaeology. Edited by Valerie Pinsky and Alison Wylie. Cambridge: Cambridge University Press, pp. 104-16.

Timreck, Ted, and William Goetzmann. 1987. The Mystery of the Lost Red Paint People. Oley: Bullfrog Films.

Wheeler, Ryan, and Bonnie Newsom. n.d. Sacred Places and Contested Spaces in Maine: The Long Shadow of Colonial Science in the Light of Repatriation. In Sins of Our Ancestors (and of Ourselves): Confronting America's Archaeological Legacies. Edited by April Beisaw, David E. Witt, Katie Kirakosian and Ryan J. Wheeler. American Anthropological Association Archaeological Papers Series. Arlington: American Anthropological Association.

Wobst, H. Martin. 2005. Power to the (Indigenous) past and present! Or: the theory and method behind archaeological theory and method. In Indigenous Archaeologies: Decolonizing Theory and Practice. Edited by Claire Smith and H. Martin Wobst. London and New York: Taylor and Francis Group, pp. 189-206.

Wobst, H. Martin. 2010. Indigenous archaeologies: A worldwide perspective on human materialities and human rights. In Indigenous Archaeologies: A Reader on Decolonization. Edited by Margaret Bruchac, Siobhan Hart and H. Martin Wobst. Walunt Creek: Left Coast Press, pp. 17-27.

Wobst, H. Martin, and Claire Smith. 2005. Indigenous Archaeologies: Decolonizing Theory and Practice. London and New York: Taylor and Francis Group.

Wright, Shannon, Mitchell Mulholland, Timothy Binzen, Christopher Donta, and Sharon Swihart. 2004. Archaeological Overview and Assessment of Acadia National Park, Maine. Report Submitted to the National Park Service. Lowell: National Park Service. 